\title{
Efficacy of Essential Oils From Some African Spices Against Two Strains of Bacillus cereus Isolated From Vegetable Salad
}

\author{
Roseline Ekiomado Uzeh ${ }^{1} \&$ Deborah Olamide Oguntosin ${ }^{1}$ \\ ${ }^{1}$ Department of Microbiology, University of Lagos, Akoka, Lagos, Nigeria \\ Correspondence: Roseline Ekiomado Uzeh, Department of Microbiology, University of Lagos, Akoka, Lagos, \\ Nigeria. E-mail: roseline_uzeh@yahoo.com
}

Received: May 6, 2013 Accepted: September 30, 2013 Online Published: October 14, 2013

doi:10.5539/jfr.v2n6p48 URL: http://dx.doi.org/10.5539/jfr.v2n6p48

\begin{abstract}
Chemical preservatives have been used to preserve our foods against spoilage and pathogenic microorganisms over the years. Consumers now frown at this hence the need to source for preservatives from natural sources. In this investigation fifteen samples of vegetable salad were collected from retail outlets in Lagos, Nigeria dilutions of which were plated on Brilliance Bacillus cereus agar. Isolates were identified based on morphological, biochemical characteristics and reactions to API 20E and API $50 \mathrm{CHB} / \mathrm{E}$ test kit. Two strains of Bacillus cereus; $B$. cereus 1 and $B$. cereus 2 were isolated. The organism was spread evenly on Mueller -Hinton agar and wells of $5 \mathrm{~mm}$ in diameter were made on the inoculated agar with sterile cork borer. Different dilutions $(1,0.1,0.01,0.001$ $\mathrm{mg} / \mathrm{ml}$ ) of essential oils extracted from three African spices; Aframomum melegueta, Xylopia aethiopica and Piper guineense by hydro distillation method were introduced into the wells in triplicate. After incubation diameter of zones of inhibition were measured. The essential oils of the spices inhibited growth of the two strains. A. melegueta produced the greatest zone of inhibition $(14$ to $24 \mathrm{~mm})$ and with the lowest minimum inhibitory concentration (MIC) of $31.25 \mathrm{mg} / \mathrm{ml}$, followed by X. aethiopica $(10$ to $18 \mathrm{~mm})$ with MIC of $62.5 \mathrm{mg} / \mathrm{ml}$ and $P$. guineense (11 to $15 \mathrm{~mm}$ ) and MIC of 125 and $250 \mathrm{mg} / \mathrm{ml}$ against $B$. cereus 1 and B. cereus 2 respectively. $P$. guineense was the least inhibitory. However, $B$. cereus 1 was more sensitive (inhibition zone of 12 to $24 \mathrm{~mm}$ ) to the essential oils of the spices than $B$. cereus 2 (inhibition zone of 10 to $17 \mathrm{~mm}$ ). The higher the concentration of the essential oils the greater the resultant zones of inhibition. The spices especially $A$. melegueta have proved very efficient in the inhibition of $B$. cereus a pathogen obtained from vegetable salad. The spices can therefore help in ensuring food safety.
\end{abstract}

Keywords: spices, essential oils, zone of inhibition, Bacillus cereus, vegetable salad

\section{Introduction}

According to World Health Organization (2007), consumption of foods contaminated with pathogenic microorganisms is a threat to human health. Friedman et al. (2007) reported that food processors, food safety researchers have been increasingly concerned with the growing number of food borne illness outbreak caused by some pathogens. There have been well-documented reports substantiating the role of B. cereus as a food poisoning organism (Whong \& Kwaga, 2007). According to Arnesen et al. (2008), B. cereus has a wide distribution in nature, frequently isolated from soil and growing plants, but it is also well adapted for growth in the intestinal tract of insects and mammals. It is frequently isolated from milk and dairy products. It is found in rice, rice products, oriental dishes and ingredient. Emetic syndrome caused by B. cereus is highly associated with rice and rice products (Narang, 2004).

Reduction in the incidence of food poisoning has been a major challenge to researchers. As a result of this and negative consumer perceptions of artificial preservatives, attention is shifting towards alternatives that are obtained from plant extracts (Mihajilov-Krstev et al., 2010). Dobre et al. (2011) reported that in the variety of techniques available for conservation, food industry is investigating other techniques to replace traditional methods of conservation due to high demand by consumers for tasty and natural food. Spices are very important in human diet. They have been used for many years to improve the flavor, colour and aroma of food. In addition to boosting flavor, spices are also known for their preservative and medicinal value which forms one of the oldest sciences and modern science has started paying attention to the properties of spices (Chaudhry \& Tariq 2006; Lai, 2004). According to Levetin and Mc Mahon (2006), there is no evidence of how primitive people first 
discovered spices, but it is reasonable to assume that they were attracted to the pleasant aromas of these plants and found many uses of them. According to Ceyhan et al. (2012), medicinal plants such as spices and aromatic vegetable materials, have been used for a wide variety of purposes for many thousands of years in Turkey and all over the World.

According to Delamare et al. (2007), it has long been recognized that some essential oils have antibacterial properties and these have been reviewed in the past as the antibacterial properties of spices but relatively recent enhancement of interest in 'green' consumerism has led to the renewal of scientific interest in these substances. According to Fleischer et al. (2008) essential oils or their constituents are odoriferous substances from plants and are extensively used as medicinal products, in the food industry as flavors and in the cosmetic industry as fragrances. Many of these oils have been shown to exert broad spectrum antimicrobial activity. Although the flavor of spices may have been the initial reason for their use by people, their antimicrobial properties may have been an added benefit for their continued use. Study, which summarized many laboratory tests, has shown compelling evidence that spices inhibit or kill many food-borne bacteria. These researches suggest that food preservation may have been the main reason why spices were incorporated into the human diet (Levetin \& Mc Mahon, 2006). Biological activity of essential oils depends on their chemical composition, which is determined by the plant genotype and is greatly influenced by several factors such as geographical origin and environmental and agronomic conditions. Many spices exert antimicrobial activity due to their essential oil fractions. The composition, structure, as well as functional groups of the oils play an important role in determining their antimicrobial activity. The compounds containing phenolic groups are usually most effective (Rota et al., 2004).

Friedman et al. (2007) stated that several antimicrobial wine recipes, each consisting of red or white wine extracts of oregano leaves with added garlic juice and oregano oil were bactericidal against B. cereus, Escherichia coli O157:H7, Listeria monocytogenes, and Salmonella enterica. Olive powder also exhibited bacteriostatic effect against B. cereus (Ferrer et al., 2008). Carvacrol, a natural antimicrobial compound present in the essential oil fraction of oregano and thyme, is bactericidal towards B. cereus (Ultee et al., 2002). The use of chemical preservatives in the prevention of pathogenic and spoilage microorganisms in foods has lead to negative health effects. Microorganisms have also been known to have acquired resistance against most of the chemical preservatives over the years, the aim of the present investigation therefore, is to isolate and identify $B$. cereus from vegetable salad and also assess the antibacterial effect of essential oils of some African spices on the isolated B. cereus with a view to establishing the possible role of these spices in enhancing food safety.

\section{Materials and Methods}

\subsection{Collection of Vegetable Salad}

A total of fifteen samples of vegetable salad were purchased from food outlets at Mushin, Oshodi and Yaba in Lagos, Nigeria. They were taken to the laboratory for analysis without delay.

\subsection{Isolation of Bacillus cereus}

Using aseptic technique, $50 \mathrm{~g}$ of the sample was weighed and introduced into sterilized stomacher, $450 \mathrm{ml}$ sterile distilled water was added and blended for 2 minutes at high speed (10,000-12,000 rpm). Serial dilutions were made up to $10^{-6}$ and approximately, $1 \mathrm{ml}$ aliquots of dilutions were surface plated in duplicates on Brilliance Bacillus cereus Agar. The plates were incubated at $37{ }^{\circ} \mathrm{C}$ for $24 \mathrm{~h}$. Following incubation, the plates were examined, left at room temperature $\left(25^{\circ} \mathrm{C}\right)$ for another $24 \mathrm{~h}$ and re-examined. Presumptive Bacillus cereus colonies were green in colour. Representative colonies of B. cereus were gram-stained (Whong \& Kwaga, 2007)

\subsection{Characterization and Identification of Bacterial Isolates}

Pure cultures of bacterial isolates were identified on the basis of their morphology, biochemical characteristics and reactions to API test kits. API 20E was used in conjunction with API $50 \mathrm{CHB} / \mathrm{E}$ test kit

\subsection{Collection of Spices}

Dried fruits of Aframomum melegueta, Xylopia aethiopica and Piper guineense used for this work were purchased from Mushin market in Lagos State, Nigeria. The spices were identified in Botany Department, University of Lagos, Nigeria.

\subsection{Extraction of Essential Oil}

Dried fruits of A. melegueta, X. aethiopica, P. guineense were processed by exposing two hundred grams of fresh plant material to air dry at room temperature $\left(28^{\circ} \mathrm{C} \pm 2\right)$ in the laboratory for $4-5$ days. The materials were pulverized in a Waring Moulineax blender for 3-5 minutes and passed through a sieve of $0.1 \mathrm{~mm}$ mesh size to standardize particle size. They were kept in brown envelopes at room temperature before extraction of the 
essential oil. Extraction of the essential oil was by Hydrodistillation method. Two hundred gram $(200 \mathrm{~g})$ of the powdered plant material was hydrodistilled using a modified Clevenger type apparatus. This allowed the oils to be captured in the steam and extracted into n-hexane at $100-110{ }^{\circ} \mathrm{C}$ for $3 \mathrm{~h}$. The oil extracted into $2 \mathrm{ml}$-hexane was carefully dispensed, dried with $\mathrm{Na}_{2} \mathrm{SO}_{4}$ and kept in tinted vials at $4{ }^{\circ} \mathrm{C}$ until further analysis. The n-hexane is volatile and so will esvaporate from the essential oil at the end of extraction and after exposure. The isolation was carried out three (3) times on the plant material for sufficient quantity for bioassay (U.S Pharmacopeia, 2007).

\subsection{Antimicrobial Activity}

The testing of the bacterial cultures for the inhibitory effect of essential oil of A. melegueta, $X$. aethiopica, $P$. guineense at different concentrations $(1,0.1,0.01,0.001 \mathrm{mg} / \mathrm{ml})$ using dimethyl sulfoxide (DMSO) as diluent, was performed by using well diffusion method (Das et al., 2010). The active cell suspension $(0.1 \mathrm{ml})$ of the test organism was spread uniformly with the help of sterile swab stick on Mueller -Hinton agar. Four wells of $5 \mathrm{~mm}$ diameter each were made on the inoculated agar medium using sterilized cork borer. Measured quantity $(100 \mu l)$ of each concentration was introduced into the wells with sterilized pipette. For each test organism, plates were prepared in duplicate per extract. Negative control was prepared using the diluent and extracting solvent. Streptomycin and Chloramphenicol $(30 \mu \mathrm{g} / \mathrm{ml})$ were used as positive control against the test organism. Plates were incubated at $37^{\circ} \mathrm{C}$ for 24 hours before being examined for zones of inhibition (Jeyakumar et al., 2011).

\subsection{Determination of Minimum Inhibitory Concentration (MIC)}

The minimum inhibitory concentration of each spice extract was determined by a slight modification of the tube dilution method (Bryant, 1981). In a set of ten sterile capped test tubes using DMSO as diluent, doubling dilutions were made from the different extracts to get graded concentrations in $\mathrm{mg} / \mathrm{ml}$ of $1000,500,250,125$, $62.5,31.25,15.63,7.81,3.91,1.95$ and a tube containing only the diluent as the sensitivity control. The active cell suspension $(0.1 \mathrm{ml})$ of the test organism was spread with the help of sterile swab stick on Mueller - Hinton agar. Wells of $5 \mathrm{~mm}$ diameter each were made on inoculated agar using sterilized cork borer. Measured quantity $(100 \mu \mathrm{l})$ of each concentration was introduced into the wells with the help of pipette. For each test organism, plates were prepared in duplicate per extract (Jeyakumar et al., 2011). The wells were sufficiently spaced to avoid overlapping of zones of inhibition. The minimum concentration of the different spice extracts that inhibited the growth of the test organisms was taken as the MIC.

\section{Result}

The isolates obtained from the vegetable salad were about $5 \mathrm{~mm}$ in diameter and had distinctive rough turquoise to peacock blue colour. They were gram positive endospore forming rods, catalase and casein positive.

Bacillus cereus isolates were further identified as B. cereus 1 and B. cereus 2 using the API 50 CHB medium. B. cereus 1 fermented glycerol, D-ribose, D-glucose, D-fructose, D-mannose, N-acetyl glucosamine, arbutin, esculin ferric citrate, salicin, D-celiobiose, D-maltose, D-saccharose, D-trehalose, amidon, glycogen and potassium gluconate. B. cereus 2 fermented the above sugars except glycerol, D-mannose and postassium gluconate.

Both strains identified did not ferment erythritol, D-xylose, L-xylose, D-adonitol, methyl- $\beta$ D-xylopyranoside, D-galactose, L-sorbose, L-rhamnose, dulcitol, inositol, D-mannitol, D-sorbitol, methyl-cd-mannopyranoside, methyl-ad-glucopyranoside, amygdalin, D-lactose,D-melibiose, inulin, D-melezitose, D-raffinose, xylitol, gentiobiose, D-turanose, D-lyxose, D-tagatose, D-fucose,L-fucose, D-arabitol, L-arabitol, potassium 2-ketogluconate and potassium 5-ketogluconate. These fermentation results helped in the identification of the two strains.

Table 1 shows the plant part, volume of solvent used, amount of spices used and volume of each extract. The colour of the spices oils was yellow, with spicy characteristic odour. The oil yield was found to be $2.05 \%(\mathrm{v} / \mathrm{w})$ in A. melegueta, $4.08 \%(\mathrm{v} / \mathrm{w})$ in X. aethiopica (which is similar to that obtained by Elhassan et al. (2010), and $4.05 \%(\mathrm{v} / \mathrm{w})$ in P. guineense. X.aethiopica appears to be richer in oil than other spices, while A. melegueta was the poorest. 
Table 1. Yield of extract of spices

\begin{tabular}{cccccc}
\hline Spices & plant part & $\begin{array}{c}\text { volume of hexane used } \\
(\mathrm{ml})\end{array}$ & $\begin{array}{c}\text { weight of spices } \\
(\mathrm{g})\end{array}$ & $\begin{array}{c}\text { volume of extract } \\
(\mathrm{v} / \mathrm{m})\end{array}$ & oil colour \\
\hline A. melegueta & fruits & 2 & 200 & 2.08 & yellow \\
X. aethiopica & fruits & 2 & 200 & 4.08 & yellow \\
P. guineense & seeds & 2 & 200 & 4.05 & yellow \\
\hline
\end{tabular}

The essential oils of A. melegueta, X. aethiopica and P. guineense inhibited growth of the two strains, B. cereus 1 and $B$. cereus 2 (Tables 2-4). This was shown by the production of zones of inhibition which ranged from 10 to $24 \mathrm{~mm}$, which means that the isolates were sensitive to all the spice extracts with different zones of inhibition at different concentrations. The essential oil of $A$. melegueta had the greatest inhibitory property with zone of inhibition of 14 to $24 \mathrm{~mm}$ (Table 2), followed by $X$. aethiopica with inhibition zone of 10 to 18 (Table 3) and $P$. guineense with zone of inhibition of 11 to 15 (Table 4). However, B. cereus 1 (with inhibition zone of 12 to 24 $\mathrm{mm}$ ) was more sensitive to the essential oils than B. cereus 2 (with inhibition zone of 10 to $17 \mathrm{~mm}$ ). The higher the concentration of the essential oils the greater the resultant zones of inhibition. Streptomycin (positive control) also produced zones of inhibition of 21 and $19 \mathrm{~mm}$ against $B$. cereus 1 and B. cereus 2 respectively. The DMSO (negative control) showed no antimicrobial activity on the test organisms because no zone of inhibition was produced.

Table 2. Antibacterial activity of essential oil from Aframomum melegueta

\begin{tabular}{lcc}
\hline Concentration of spice $(\mathrm{mg} / \mathrm{ml})$ & \multicolumn{2}{c}{ Zones of inhibition $(\mathrm{mm})$} \\
\cline { 2 - 3 } & Bacillus cereus 1 & Bacillus cereus 2 \\
\hline 1 & 24 & 17 \\
0.1 & 24 & 16 \\
0.01 & 22 & 14 \\
0.001 & 20 & 14 \\
Negative control (Dimethyl sulfoxide) & - & - \\
Positive control (Streptomycin) & 21 & 19 \\
\hline
\end{tabular}

-: No zone of inhibition.

Table 3. Antibacterial activity of essential oil from Xylopia aethiopica

\begin{tabular}{lcc}
\hline Concentration of spice $(\mathrm{mg} / \mathrm{ml})$ & \multicolumn{2}{c}{ Zones of inhibition $(\mathrm{mm})$} \\
\cline { 2 - 3 } & Bacillus cereus 1 & Bacillus cereus 2 \\
\hline 1 & 18 & 14 \\
0.1 & 17 & 14 \\
0.01 & 13 & 12 \\
0.001 & 12 & 10 \\
Negative control (Dimethyl sulfoxide) & - & - \\
Positive control (Streptomycin) & 21 & 19 \\
\hline
\end{tabular}

-: No zone of inhibition.

The result of the minimum inhibitory concentrations of the different spice extracts is shown on Table 5. The MIC ranged from 31.25 to $250 \mathrm{mg} / \mathrm{ml}$. The least minimum inhibitory concentration obtained was $31.25 \mathrm{mg} / \mathrm{ml}$ and from A. melegueta which also produced the largest zones of inhibition against the test organisms and hence the most inhibitory of the three spices. This was followed by MIC obtained from X. aethiopica which was 62.5 
$\mathrm{mg} / \mathrm{ml}$ and this spice was the second most inhibitory of the spices. P. guineense produced the highest MIC of 125 and $250 \mathrm{mg} / \mathrm{ml}$ against $B$. cereus 1 and $B$. cereus 2 respectively; it was the least inhibitory spice against the test organisms and especially B. cereus 2 .

Table 4. Antibacterial activity of essential oil from Piper guineense

\begin{tabular}{lcc}
\hline Concentration of spice $(\mathrm{mg} / \mathrm{ml})$ & \multicolumn{2}{c}{ Zones of inhibition $(\mathrm{mm})$} \\
\cline { 2 - 3 } & Bacillus cereus 1 & Bacillus cereus 2 \\
\hline 1 & 15 & 13 \\
0.1 & 15 & 12 \\
0.01 & 14 & 11 \\
0.001 & 12 & 10 \\
Negative control (Dimethyl sulfoxide) & - & - \\
Positive control (Streptomycin) & 21 & 19 \\
\hline
\end{tabular}

-: No zone of inhibition.

Table 5. Minimum inhibitory concentration (MIC) of the tested essential oils

\begin{tabular}{lccc}
\hline & \multicolumn{3}{c}{ Minimum inhibitory concentration $(\mathrm{mg} / \mathrm{ml})$} \\
\cline { 2 - 4 } Bacterial strains & A. melegueta & X. aethiopica & P. guineense \\
\hline B. cereus 1 & 31.25 & 62.5 & 125 \\
B. cereus 2 & 31.25 & 62.5 & 250 \\
\hline
\end{tabular}

\section{Discussion}

This study has demonstrated that essential oils from these spices have antimicrobial properties against the tested organisms. Different parts of medicinal plants are usually selected for antimicrobial activity. Factors such as antimicrobial efficacy, sensory properties and presence of different components in the essential oils contribute to what part of the plant that is used (Gutierrez et al., 2008). Ntonifor (2011) stated that the plant, especially the spicy edible fruit is used as a spice and flavouring agent in food but also medicinally as well as to control plant pests and diseases. This conforms to the results obtained since the spices were discovered to possess antimicrobial activities against the test organisms.

The activity of the extract against the test organisms reduced with decrease in concentration of the essential oils. Therefore, the antibacterial activities of these extracts may be related to the concentration of the bioactive compounds present which gradually decreased with each successive dilution. This is in line with the work carried out by Ultee et al. (2002) who observed a decrease in the sensitivity of $B$. cereus towards carvacrol after growth in the presence of non-lethal carvacrol concentrations. A. melegueta showed the greatest zones of inhibition against the test organisms. This was followed by $X$. aethiopica and $P$. guineense respectively. Considering the test organisms, B.cereus 1 was more sensitive than B.cereus 2 to the essential oils from these spices. Streptomycin which served as a positive control showed equivalent antimicrobial activity, while dimethyl sulfoxide (DMSO) which served as a negative control showed no antimicrobial activity. The MIC of the plant extracts showed that the MIC of $A$. melegueta for the test organisms was the lowest, followed by that of $X$. aethiopica, and the highest was from $P$. guineense. The MIC obtained from the spices corresponds with their level of inhibitory property towards the test organisms. This proves a possible greater efficacy of A. melegueta at a lower concentration than the other spices especially $P$. guineense from which the highest concentration was required to inhibit the test organisms. The results obtained are comparable with previous study (Jeyakumar et al., 2011), where essential oil of Mentha piperita was used against B. cereus.

\section{Conclusion}

However, the spices investigated in this study will serve as useful antibacterial agents especially with regards to B. cereus. Therefore, they will be useful in ensuring food safety since B. cereus is a known food pathogen. The spices are natural preservatives and so they are of advantage over chemical preservatives which consumers now 
shy away from because of their negative health effects and the resistance that microorganisms develop towards some of them. The only limitation however, is the very low concentration of these spices applied normally in our foods which may not be enough to give results obtained in this study especially in foods contaminated with this pathogen.

\section{References}

Arnesen, L. P., Fagerlund, A., \& Granum, P. E. (2008). From soil to gut: Bacillus cereus and its food poisoning toxins. FEMS Microbiology Review, 32, 579-606. http://dx.doi.org/10.1111/j.1574-6976.2008.00112.x

Bryant, M. C. (1981). Laboratory control of antimicrobial chemotherapy (pp. 102-123). Bristol, London, Boston: John Wright and Sons Ltd.

Ceyhan, N. Keskin, D., \& Ugur, A. (2012). Antimicrobial activities of different extracts of eight plant species from four different family against some pathogenic microorganisms. Journal of Food, Agriculture and Environment, 10(1), 193-197.

Chaudhry, N., \& Tariq. (2006). Bactericidal activity of Black pepper, Bay leaf, Aniseed and Coriander against Oral isolates. Pakistan Journal of Pharmaceutical Science, 19(3), 214-218.

Das, K., Tiwari, R., \& Shrivastava, D. (2010). Techniques for evaluation of medicinal plant products as antimicrobial agent: Current methods and future trends. Journal of Medicinal Plants Research, 4(2), 104-111.

Delamare, A. P., Pistorello, I. T., Artico, L., Serafini, L., \& Echeverrigaray, S. (2007). Antibacterial activity of the essential oils of Salvia officinalis L. and Salvia triloba L. cultivated in South Brazil. Food Chemistry, 100, 603-608. http://dx.doi.org/10.1016/j.foodchem.2005.09.078

Dobre, A., Gagiu, V., \& Niculita, P. (2011). Preliminary Studies on the Antimicrobial Activity of Essential oils against Food borne Bacteria and Toxigenic Fungi. The Annals of the University Dunarea de Jos of Galati Fascicle VI-Food Technology, 35(2), 16-26.

Elhassan, I. A., Elainin, E. E., \& Hussein Ayoub, S. M. (2010). Chemical Composition of essential oil in dried fruits of Xylopia aethiopica from Sudan. Open Acess Journal of Medicinal and Aromatic Plants, 1(1), 24-28.

Ferrer, C., Ramon, D., Muguerza, B., Marco, A., \& Martinez, A. (2008). Effect of olive powder on the growth and inhibition of Bacillus cereus. Foodborne Pathogenic Disease, 10, 1455- 1459.

Fleischer, T. C., Mensah, M. L., Mensah, A. Y., Komlaga, G., Gbedema, S. Y., \& Skaltsa, H. (2008). Antimicrobial Activity of Essential oils of Xylopia aethiopica. African Journal of Traditional and Complementary Alternative Medicine, 5(4), 391-393.

Friedman, M., Henika, P. R., Levin, C. E., \& Mandrell, R. E. (2007). Recipes for antimicrobial wine marinades against Bacillus cereus, Escherichia coli O157:H7, Listeria monocytogenes, and Salmonella enterica. Journal of Food Science, 72, 207-213. http://dx.doi.org/10.1111/j.1750-3841.2007.00418.x

Gutierrez, J., Barry-Ryan, C., \& Bourke, P. (2008). The anti-microbial efficacy of plant essential oil combinations and interactions with food ingredients. International Journal of Food Microbiology, 124(1), 91-97. http://dx.doi.org/10.1016/j.ijfoodmicro.2008.02.028

Jeyakumar, E., Lawrence, R., \& Pal, T. (2011). Comparative evaluation in the efficacy of peppermint (Menthra piperita) oil with standard antibiotics against selected bacterial pathogens. Asian pacific Journal of Tropical Biomedicine, 10, 253-257.

Lai, P. K., \& Roy, J. (2004). Antimicrobial and Chemopreventative Properties of Herbs and Spices. Current Medical Chemistry, 11(11), 1451-1460. http://dx.doi.org/10.2174/0929867043365107

Levetin, E., \& Mc Mahoon, K. (2006). Herbs and Spices In: Plants and Society: The Botanical Connection to our Lives (pp. 285-289). New York: Mc Graw Hill Companies.

Logan, N. A., Carman, J. A., Melling, J., \& Berkeley, R. C. (1995). Identification of Bacillus anthracis by API tests. Journal of Medicinal Microbiology, 20, 75-85. http://dx.doi.org/10.1099/00222615-20-1-75

Mihajilov-Krstev, T., Radnovie, D., Kitic, D., Radic, Z., \& Zlatkovic, B. (2010). Antimicrobial activity of Satureja hortensis L. essential oil against pathogenic microbial strains. Archaeological Biological Science Belgarade, 62(1), 159-166. http://dx.doi.org/10.2298/ABS1001159M

Narang, S. P. (2004). Microorganism in Foods In: Food Microbiology Methods of Enumeration (3rd ed.) (pp. 
170-173). New Delhi: APH Publishing Cooperation.

Ntonifor, N. N. (2011). Potentials of Tropical African Spices as sources of Reduced Risk Pesticides. Journal of Entomology, 8(1), 16-26. http://dx.doi.org/10.3923/je.2011.16.26

Peter, K. V. (2004). Introduction to Herbs and Spices In Handbook of Herbs and Spices (pp. 1-6). Woodhead Publishing Limited, Cambridge England. http://dx.doi.org/10.1533/9781855738355.1

Pundir, R., \& Jain, P. (2010). Comparative studies on the Antimicrobial activity of Black pepper (Piper nigrum) and Tumeric (Curcuma longa) extracts. International Journal of Applied Biology and Pharmaceutical Technology, 1(2), 492- 500 .

Rota, C., Carraminana, J., Burillo, J., \& Herrera, A. (2004). In vitro antimicrobial activity of essential oils from aromatic plants against selected foodborne pathogens. Journal of Food Protection, 67, 1252-1256.

Ultee, A., Bennik, M. H., \& Moezelaar, R. (2002). The phenolic hydroxyl group of carvacrol is essential for action against the food-borne pathogen Bacillus cereus. Applied Environmental Microbiology, 68, 1561-1568. http://dx.doi.org/10.1128/AEM.68.4.1561-1568.2002

U.S Pharmacopeia. (2007). U.S Pharmacopeia National Formulary. The Official compendia of Standards, 1, 200-202.

WHO-Food Safety \& Foodborne Illness, World Health Organization Fact Sheet 237, reviewed March 2007.

Whong, C. M. Z., \& Kwaga, J. K. P. (2007). Antibiograms of Bacillus cereus isolates from some Nigerian Foods. Nigerian Food Journal, 25(1), 178-183. http://dx.doi.org/10.4314/nifoj.v25i1.33667

\section{Copyrights}

Copyright for this article is retained by the author(s), with first publication rights granted to the journal.

This is an open-access article distributed under the terms and conditions of the Creative Commons Attribution license (http://creativecommons.org/licenses/by/3.0/). 